\section{Differences in corneal thickness and corneal endothelium related to duration in Diabetes}

JS Lee ${ }^{1}$, BS Oum¹ ${ }^{1}$ HY Choi ${ }^{1}$, JE Lee ${ }^{1}$ and BM Cho²

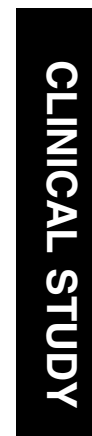

Keywords: central corneal thickness; duration of diabetes; pachymetry; partial correlation coefficient; specular microscopy

\section{Introduction}

Diabetes mellitus is associated with structural changes in corneal endothelial cells and their thickness. ${ }^{1-5}$ Many clinical evidences have shown that patients with diabetes have functional abnormalities such as a higher corneal autofluorescence, lower corneal sensitivity, greater baseline corneal thickness, less endothelial cell density, and increased endothelial permeability to fluorescein after intraocular surgery. ${ }^{6-8}$

However, there have not been many studies that provide understanding of the alterations in the diabetic cornea by evaluating the corneal structure and correlating the changes with the diabetic duration. ${ }^{9,10}$ Thus, we performed our study to evaluate the differences of central corneal thickness and corneal endothelial cell morphology between diabetics and agematched healthy normal subjects. In addition, we also evaluated the correlation between each of these values and the diabetic duration by using a partial correlation coefficient to control for the age of the patients.

\section{Patients and methods}

We examined 200 patients with insulindependent diabetes (99 males and 101 females) and 100 control subjects (54 males and 46 females) in this study. The age range of diabetic group was $23-83$ years (mean $57.5 \pm 8.5$ years) and the mean age of the control group was 33-81 years (mean: $52.8 \pm 8.6$ years). The
${ }^{1}$ The Department of Ophthalmology, College of Medicine, Pusan,

Korea

${ }^{2}$ Department of Prevention, College of Medicine, Pusan National University, Pusan,

Korea

Correspondence: JS Lee, Department of Ophthalmology, College of Medicine, Pusan National University, 1-10, Ami-Dong, Seo-Gu, Pusan 602-739, Korea. Tel: + 82512407323 ; Fax: + 82512427341

E-mail: jongsool@ pusan.ac.kr

Received: 19 October 2004 Accepted: 15 February 2005 Published online: 15 April 2005

Proprietary interest: This study was supported by Medical Research Institute Grant 2003-36, Pusan National University Hospital Pusan, Korea

This article has been presented at the European Society of Cataract and Refractive Surgeons in September 2003 Pusan National University, 
Table 1 Demographics of control and diabetic patients

\begin{tabular}{lcc}
\hline & Normal group & Diabetics \\
\hline Patients $(n)$ & 100 & 200 \\
Mean age/range (years) & $56.8 / 33-81$ & $57.5 / 23-83$ \\
Sex (male/female) $(n)$ & $54 / 46$ & $99 / 101$ \\
\hline
\end{tabular}

duration of diabetes was from 2-30 years (mean: $10.8 \pm 5.9$ years) (Table 1). All the diabetic patients were divided into two groups according to diabetic duration of 10 years or less than 10 years.

Ophthalmologic examination included a complete medical history, slit-lamp examination, ultrasound pachymetry (Bio Vision Instrument Pachymetry, USA), videokeratography (Canon, Japan), endothelial cell count and morphology (Konan Noncon Robo 8000, Japan), and a binocular indirect ophthalmoscopy fundus examination. Those patients who had any type of diabetic retinal lesion were evaluated by a retinal specialist who decided whether to diagnosis such lesions as normal fundus or as background diabetic retinopathy. None of the patients used topical ocular medications, and any patients having a history of ocular disease, previous ophthalmic intervention, laser treatment, proliferative diabetic retinopathy, and contact lens wear were excluded from the study.

Corneal thickness was measured using an ultrasound pachymetry. Each corneal thickness measurement was the mean of 10 successive pachometry readings. Two measurements were completed on each eye at each session, and these were averaged to provide a single value for the eye at that session.

Specular microscopy of the central endothelium was performed on both eyes by using a specular microscope. This device autotracts the cornea and autofocuses on the endothelium without touching the cornea. It also provides high magnification, good image quality and the capability for semiautomated, computer-assisted cell density determination, and morphometric analysis. Using the 'dot' method, we then digitized 100 cells by touching the cell apices with a graphic tablet pen, and we analysed the cell sizes according to a variety of factors including cell density, the CV of cell area (SD/mean), and the percentage of hexagonal cells. All statistical tests and analyses were based on only right eye data.

We compared the values of corneal factors such as corneal thickness, and endothelial cell morphology in diabetics and normal persons by using ANACOVA testing that adjusted for age of the patients. We also evaluated the correlation between the corneal factors in diabetes and the duration of diabetes using a partial correlation coefficient that controlled for age.

\section{Results}

The mean duration of diabetes was $10.8 \pm 5.9$ years, and 111 patients had diabetes for less than 10 years (Table 2). There was no statistically significant difference between the subjects with diabetes and normal persons, and between data for the right and left eyes $(P>0.05)$. In general, there were thicker central corneal thicknesses, less endothelial cell density, less hexagonality, and more irregular cell sizes for diabetics, as compared with the normal persons $(P<0.05)$ (Table 3$)$.

The mean corneal thickness was significantly higher in diabetic $(588.2 \pm 2.7 \mu \mathrm{m})$ than in the control group $(567.8 \pm 3.8 \mu \mathrm{m})(P<0.05)$. The mean corneal thickness was significantly higher for diabetes of over 10 years' duration $(595.9 \pm 4.2 \mu \mathrm{m})$ than for diabetes of under 10 years' duration $(582.2 \pm 3.7 \mu \mathrm{m})(P<0.05)$. There was a significant difference in the central corneal thickness between the two groups of diabetic patients $(P<0.05)$ (Tables 3 and 4).

The mean cell density of the corneal endothelium was significantly less in diabetics $\left(2577.2 \pm 27.3 \mathrm{cell} / \mathrm{mm}^{2}\right)$ than in the control group $\left(2699.9 \pm 38.7 \mathrm{cell} / \mathrm{mm}^{2}\right)$ $(P<0.05)$. The corneal endothelial cell density was higher for diabetes of under 10 years' duration $\left(2617.6 \pm 34.3 \mathrm{cell} / \mathrm{mm}^{2}\right)$ than for diabetes of over 10 years' duration $\left(2525.7 \pm 38.3 \mathrm{cell} / \mathrm{mm}^{2}\right)$, and this was not a significant difference $(P>0.05)$. Also, the mean value of

Table 2 Age distributions in control and diabetic patients

\begin{tabular}{lcccc}
\hline \multirow{3}{*}{ Control (\%) } & \multicolumn{3}{c}{ Diabetics (\%) } \\
\cline { 3 - 4 } & & \multicolumn{2}{c}{ Duration } & Total \\
\cline { 3 - 4 } & & $\leq 10$ years & $>10$ years \\
\hline$<49$ & $14(14.0)$ & $20(18.0)$ & $8(9.0)$ & $28(14.0)$ \\
$50-59$ & $52(52.0)$ & $46(41.5)$ & $52(58.4)$ & $98(49.0)$ \\
$\geq 60$ & $34(34.0)$ & $45(40.5)$ & $29(32.6)$ & $74(37.0)$ \\
& $100(100)$ & $111(100)$ & $89(100)$ & $200(100)$ \\
\hline
\end{tabular}

Table 3 A comparison of age-adjusted mean value between control and diabetic patients (mean \pm SE)

\begin{tabular}{lcccc}
\hline & $\begin{array}{c}\text { Central } \\
\text { corneal } \\
\text { thickness } \\
(\mu \mathrm{m})\end{array}$ & $\begin{array}{c}\text { Endothelial } \\
\text { cell density } \\
\left(\text { cell/mm } / \mathrm{mm}^{2}\right)\end{array}$ & $\begin{array}{c}\text { Hexagonality } \\
(\%)\end{array}$ & $\begin{array}{c}\text { Coefficient } \\
\text { of variation }\end{array}$ \\
\hline Control & $567.8 \pm 3.8$ & $2699.9 \pm 38.7$ & $60.6 \pm 0.9$ & $35.2 \pm 0.6$ \\
Diabetics & $588.2 \pm 2.7$ & $2577.2 \pm 27.3$ & $52.7 \pm 0.6$ & $38.2 \pm 0.4$ \\
$P$-value & $<0.001$ & 0.010 & $<0.001$ & 0.036 \\
\hline
\end{tabular}


Table 4 A comparison of age-adjusted mean value according to the duration of diabetes (mean \pm SE)

\begin{tabular}{lcccc}
\hline $\begin{array}{l}\text { Duration } \\
\text { of diabetes } \\
\text { (years) }\end{array}$ & $\begin{array}{c}\text { Central } \\
\text { corneal } \\
\text { thickness } \\
(\mu \mathrm{m})\end{array}$ & $\begin{array}{c}\text { Endothelial } \\
\text { cell density } \\
\left(\text { cell } / \mathrm{mm}^{2}\right)\end{array}$ & $\begin{array}{c}\text { Hexagonality } \\
(\%)\end{array}$ & $\begin{array}{c}\text { Coefficient } \\
\text { of } \\
\text { variation }\end{array}$ \\
\hline$\leq 10$ & $582.2 \pm 3.7$ & $2617.6 \pm 34.3$ & $53.1 \pm 0.9$ & $37.9 \pm 0.5$ \\
$>10$ & $595.9 \pm 4.2$ & $2525.7 \pm 38.3$ & $52.3 \pm 1.0$ & $39.1 \pm 0.6$ \\
$P$-value & 0.015 & 0.075 & 0.547 & 0.042 \\
\hline
\end{tabular}

Table 5 Partial correlation coefficients controlling for age

\begin{tabular}{lcccc}
\hline & $\begin{array}{c}\text { Central } \\
\text { corneal } \\
\text { thickness } \\
(\mu \mathrm{m})\end{array}$ & $\begin{array}{c}\text { Endothelial } \\
\text { cell density } \\
(\text { cell/mm })^{2}\end{array}$ & $\begin{array}{c}\text { Hexagonality } \\
(\%)\end{array}$ & $\begin{array}{c}\text { Coefficient } \\
\text { of } \\
\text { variation }\end{array}$ \\
\hline $\begin{array}{l}\text { Duration } \\
\text { of diabetes }\end{array}$ & 0.169 & -0.132 & -0.016 & -0.017 \\
$P$-value & 0.017 & 0.064 & 0.825 & 0.814 \\
\hline
\end{tabular}

hexagonality was significantly higher for diabetics than for normal persons $(P<0.05)$, but there was no significant difference between the diabetic patients having disease of over and under 10 years' duration $(P>0.05)$. The mean value of the coefficient of variation in cell size was significantly higher in diabetics $(38.2 \pm 0.4)$ than in the control group $(35.4 \pm 0.6)(P<0.05)$. Also the mean value of coefficient of variation in cell size was significantly higher for diabetes of over 10 years' duration than for diabetes of under 10 years' duration $(P<0.05)$ (Tables 3 and 4).

The central corneal thickness was significantly correlated with diabetes duration $(P<0.05)$, but the corneal endothelial morphology such as cell density, hexagonality, and the coefficient of variation in cell size were not correlated $(P>0.05)$ (Table 5).

\section{Discussion}

The morphometry of corneal endothelial cells and central corneal thickness values in diabetic patients were not appreciably different from those found in normal person's without diabetes. ${ }^{8,11-14}$ In fact, the central corneal thickness of diabetics is thicker than that of normal persons, ${ }^{10}$ and diabetic corneal endothelial morphology shows distinct differences compared with normal cornea. ${ }^{7,9-11}$ These morphological changes of the diabetic cornea were revealed by some experimental studies using mice or dogs, and the researchers reported a decrease in the corneal endothelium density, a decrease in hexagonality, and an increase in the coefficient of variation for cell size in the case of diabetes. ${ }^{3,4}$ It is thought that diabetes reduces the activity of $\mathrm{Na}^{+}-\mathrm{K}^{+}$ ATPase of the corneal endothelium, and this causes the morphological changes and permeability changes in the corneas, and then damages are caused as corneal compensation against the IOP. ${ }^{2,8}$

As seen above, studies exist on the differences of corneal factors between normal people and diabetics, but studies on the relevance of the duration of diabetes are rare. ${ }^{9,10}$ Accordingly, we compared the differences in the corneal thickness and endothelium between age-matched persons with and without diabetes, and we examined the differences of corneal factors like the endothelial cell changes depending on the duration of diabetes.

At first, the differences in the central corneal thickness and endothelial morphology between the normal group and two diabetic groups (less than 10 years and over 10 years) were analysed with ANACOVA. And then, the relation between the measurements obtained from the diabetic group and the duration of diabetes was assessed using partial correlation coefficients to adjust for age.

According to our results, diabetic patients showed significant differences compared with normal persons in terms of the central corneal thickness and morphological change of the corneal endothelium. Diabetes of over 10 years' duration showed thicker corneas, a lower corneal endothelium density, lower hexagonality ratios, and higher coefficients of variation in cell size than those patients having diabetes of under 10 years' duration. However, there were only significant differences between diabetes of over 10 years' and under 10 years' duration in corneal thickness and coefficients of variation in cell size. With regard to the corneal endothelial morphology, the coefficient of variation in cell size appears to be the most sensitive of three factors of corneal endothelial morphology: cell density, hexagonality, coefficient variation, according to the duration of diabetes. Overall, this fact is likely to suggest that polymegatism and pleomorphism may precede a decrease in cell density. ${ }^{1,15,16}$

As for the relation to the disease duration using partial correlation coefficients that controlled for age, a significant correlation was found only with the central corneal thickness; no significant correlation was found in terms of the corneal endothelial pleomorphism or polymegatism. Further surveys on large groups of diabetic patients who have had diabetes for a long period of time seem to be necessary, because the judgment criteria for the partial correlation coefficients adjusting for age may be interpreted differently. 
Keoleian et $a l^{17}$ reported that diabetic patients frequently had abnormal corneal endothelium in contrast to normal persons, but there were no significant differences in terms of function of the fluorescence permeability of the corneal thickness and endothelium. This means that the corneal endothelium of diabetic patients has a structural disorder, but the functional disorder of the corneal tissues is not affected.

Busted et $a l^{10}$ showed that the diabetic corneal thickness was significantly thicker than the normal corneal thickness, but there was no significant relation between central corneal thickness of diabetes and the diabetic duration. This difference is probably due to the fact that the mean age of their subjects (34 years) was lower than that ( 57.5 years) of our diabetic subjects. A more active compensation of the corneal endothelial pump action seems to be present in younger diabetics than in older diabetics, because the corneal thickness of diabetics depends on the increased hydration of the cornea.

Ziadi et $a l^{12}$ reported that it took longer for diabetics to recover from damaged corneal tissues compared with normal persons. As the corneal endothelium of diabetic patients has a structural disorder, a functional disorder of the diabetic corneal tissues can be caused by a stimulus like stress or trauma to the corneal tissues or from the lack of an adequate oxygen supply. ${ }^{12,14}$ Therefore, it is necessary to carefully observe functional disorders including disorders in the permeability of the corneal tissues when conducting ophthalmologic procedures such as cataract operations and PRP or when diabetics use contact lenses for a long period of time.

On the basis of our study's results, diabeties have morphological abnormalities such as greater baseline corneal thickness, a decreased endothelial cell density and percentage of hexagonality, and an increased coefficient of variation in cell size in contrast to normal persons. For diabetic durations of over 10 years, the central corneal thickness and coefficient of variation in cell size were noted to increase and cellular density and hexagonality were noted to decrease. Especially, the central corneal thickness was significantly correlated with the duration of diabetes after controlling for age.

\section{References}

1 Schultz RO, Matsuda M, Yee RW, Edelhauser HF, Schultz $\mathrm{KJ}$. Corneal endothelial changes in type I and type II diabetes mellitus. Am J Ophthalmol 1984; 98: 401-410.

2 Herse PR. Corneal hydration control in normal and alloxaninduced diabetic rabbits. Invest Ophthalmol Vis Sci 1990; 31: 2205-2213.

3 Meyer LA, Ubels JL, Edelhauser HF. Corneal endothelial morphology in the rat. Invest Ophthalmol Vis Sci 1988; 29: 940-948.

4 Yee RW, Matsuda M, Kern TS, Engerman RL, Edelhauser HF. Corneal endothelial changes in diabetic dogs. Curr Eye Res 1985; 4: 759-766.

5 Bourne WM. Clinical estimation of corneal endothelial pump function. Trans Am Ophthalmol Soc 1998; 96: 229-239.

6 Schwartz DE. Corneal sensitivity in diabetics. Arch Ophthalmol 1974; 91: 174-178.

7 Sanchez-Thorin JC. The cornea in diabetes mellitus. Int Ophthalmol Clin 1998; 38: 19-36.

8 Weston BC, Bourne WM, Polse KA, Hodge DO. Corneal hydration control in diabetes mellitus. Invest Ophthalmol Vis Sci 1995; 36: 586-595.

9 Larsson LI, Bourne WM, Pach JM, Brubaker RF. Structural and function of the corneal endothelium in diabetes mellitus type I and type II. Arch Ophthalmol 1996; 114: 9-14.

10 Busted N, Olsen T, Schmitz O. Clinical observations on corneal thickness and the corneal endothelium in diabetes mellitus. Br J Ophthalmol 1981; 65: 687-690.

11 O'Donnell C, Efron N. Corneal endothelial cell morphometry and corneal thickness in diabetic contact lens wearers. Optom Vis Sci 2004; 81: 858-862.

12 Ziadi M, Moiroux P, d'Athis P, Bron A, Brun JM, CreuzotGarcher C. Assessment of induced corneal hypoxia in diabetic patients. Cornea 2002; 21: 453-457.

13 Nieuwendaal CP, Odentahl MT, Kok JH, Venema HW, Oosting J, Riemslag FC et al. Morphology and function of the corneal endothelium after long-term contact lens wear. Invest Ophthalmol Vis Sci 1994; 35: 3071-3077.

14 Nguyen T, Soni PS, Brizendine E, Bonanno JA. Variability in hypoxia-induced corneal swelling is associated with variability in corneal metabolism and endothelial function. Eye Contact Lens 2003; 29: 117-125.

15 Lee JS, Park WS, Lee SH, Oum BS, Cho BM. A comparative study of corneal endothelial changes induced by different durations of soft contact lens wear. Graefe's Arch Clin Exp Ophthalmol 2001; 239: 1-4.

16 MacRae SM, Matsuda M, Philips DS. The effects of hard and soft contact lenses on the corneal endothelium. Am J Ophthalmol 1986; 102: 50-57.

17 Keoleian GM, Pach JM, Hodge DO, Trocme SD, Bourne WM. Structural and functional studies of the corneal endothelium in diabetes mellitus. Am J Ophthalmol 1992; 113: $67-70$. 